\title{
Komunikasi Antar Budaya pada Etnis Gayo dengan Etnis Jawa
}

\section{Intercultural Communication at The Gayo Ethnic and Javanese Ethnic}

\author{
Effiati Juliana Hasibuan*1), Indra Muda ${ }^{2)}$ \\ 1) Program Studi Ilmu Komunikasi, 2) Program Studi Administrasi Publik, \\ Fakultas Ilmu Sosial dan Ilmu Politik, Universitas Medan Area, Indonesia \\ email: effiatihsb@yahoo.co.id
}

\begin{abstract}
Abstrak
Komunikasi antar budaya adalah komunikasi yang melibatkan peserta komunikasi yang mewakili pribadi, antarpribadi atau kelompok dengan tekanan pada perbedaan latar belakang kebudayaan yang mempengaruhi perilaku komunikasi para pesertanya. Adanya perbedaan latar belakang budaya seringkali mengakibatkan terjadinya perbedaan dalam memaknai suatu peristiwa maupun dalam menanggapi isi pesan. Namun perbedaan itu tidak berarti ketika etnis Jawa menunjukkan sikap yang menghargai dan menghormati etnis Gayo demikianpun sebaliknya. Mereka mampu hidup berdampingan secara harmonis serta saling menerima kelebihan dan kekurangan masing-masing. Karakter etnis Jawa sebagai etnis pendatang yang cenderung rendah hati, nrimo ,sopan santun dalam pergaulan, gemar bergotong royong dalam kehidupan bermasyarakat menjadi daya tarik yang menimbulkan rasa aman dan penerimaan dari etnis Gayo sebagai penduduk setempat. Meskipun dalam beberapa hal kedua etnis tetap mempertahankan adat budayanya masing masing, namun hal tersebut tidak sampai menimbulkan perasaan etnosentrime yang menganggap budaya dan etnis lain lebih rendah dari budayanya. Sesungguhnya perbedaan antar etnis di Indonesia justru menjadi kekayaan budaya yang senantiasa perlu ditelaah dan dikelola kunci pemersatunya agar keharmonisan antar etnis senantiasa terjaga dan terpelihara.
\end{abstract}

Kata kunci: Etnis Gayo, Etnis Jawa, Komunikasi Antar Budaya

\begin{abstract}
Intercultural communication is communication which involved communication participants represent personal, interpersonal or group with the emphasis on differences in cultural background that affect the communication behaviour of the participants. Differences in cultural backgrounds often result in differences in meaning of an event or in response to the message content. But the difference is not meaningful when the Javanese ethnicity shows the attitude that respects the Gayo ethnic and vice versa. They are able to coexist harmoniously and receive each other's advantages and disadvantages. Javanese ethnic characters as ethnic immigrants who tend to be humble, nrimo, politeness in association, willing to work together in community life becomes an attraction that generates a sense of security and acceptance of ethnic Gayo as a local resident. Although in some respects both ethnic groups maintain their own cultural customs, but that does not cause ethnosentrime feelings that consider other cultures and ethnicities lower than other culture. Indeed, the differences between ethnic groups in Indonesia actually become a cultural richness that always needs to be studied and managed the united key therefore interethnic harmony always maintained and preserved.
\end{abstract}

Keywords: Gayo Ethnic, Java Ethnic, Intercultural Communication

How to cite: Hasibuan, E.J, \& Indra M, (2017) Komunikasi Antar Budaya pada Etnis Gayo dengan Etnis Jawa, SIMBOLIKA; 3 (2): 106-113 


\section{PENDAHULUAN}

Etnis Gayo adalah kelompok etnis yang terdapat di Provinsi Aceh yang daerahnya meliputi Kabupaten Bener Meriah, Aceh Tengah, Gayo Lues, Aceh Tenggara, Aceh Tamiang, dan Kabupaten Aceh Timur. Pada umumnya mereka menganut agama Islam yang sudah dianut secara turun temurun, sedangkan bahasa yang dipergunakan seharihari adalah bahasa Gayo. "Terkait dengan sejarah masyarakat Gayo di Kabupaten Bener Meriah masih belum terungkap dengan jelas. Bagi masyarakat Gayo sendiri, zaman purbanya dikenal lewat cerita dari mulut kemulut, baik tentang asal usul, adat istiadat, seni sastra, dan lain-lainnya" (Cut Banta Rafinis, 2004).

Etnis Gayo dapat digolongkan sebagai etnis yang memiliki pandangan luas dan terbuka terhadap etnis lainnya di Provinsi Aceh. Mereka dapat hidup saling berdampingan dengan etnis-etnis pendatang misalnya dengan etnis Jawa, etnis Minangkabau, etnis Tionghoa, etnis Batak/Mandailing dan beberapa etnis lainnya. Dari semua etnis pendatang tersebut, hubungan paling akrab terjadi dengan etnis Jawa karena karakter etnis Jawa yang lebih mampu beradaptasi dengan masyarakat setempat.

Kerukunan hidup antara etnis Gayo dengan etnis Jawa ini sempat terganggu semasa berlakunya status Daerah Operasi Militer dari tahun 1988-1998. Pada masa pemberlakuan status Daerah Operasi Militer (DOM) dengan sandi operasinya yang terkenal "Jaring Merah", banyak warga sipil menjadi korban penyiksaan dan korban jiwa akibat aparat militer salah sasaran, dan yang menjadi korbannya kebanyakan adalah masyarakat Gayo. Pada masa itu , etnis Gayo beranggapan bahwa etnis Jawa menjadi penunjuk jalan untuk menangkap atau mengeksekusi mereka dengan tuduhan menjadi pasukan atau partisipan Gerakan Aceh Merdeka (GAM), meski tuduhan tersebut terkadang keliru.
Setelah berjalan lebih kurang 10 (sepuluh) tahun, bibit konflik semakin memanas, puncaknya adalah terjadinya peristiwa pengusiran etnis Jawa dari tanah Gayo yang memaksa beberapa etnis Jawa melakukan eksodus atau meninggalkan tanah Gayo untuk pergi ke daerah lain karena adanya ancaman pembunuhan, intimidasi dan kewajiban pungutan pajak Nanggroe dari pasukan GAM.

Stagnasi sosial yang dialami masyarakat Gayo saat menyandang status Daerah Opersai Militer (DOM), menimbulkan kesulitan untuk membedakan siapa yang menjadi kawan ataupun lawan. Doktrin militer lekat dengan alasan untuk memburu pasukan Gerakan Aceh Merdeka. Penanganan gejolak sosial melalui pendekatan militer berpengaruh terhadap munculnya konflik horizontal. Tidak jarang dengan mudahnya seseorang menuduh orang lain sebagai anggota Gerakan Aceh Merdeka dan tanpa banyak proses pemeriksaan lebih lanjut, pasukan militer dengan sewenangwenang melakukan tindakan yang melanggar Hak Azasi Manusia (HAM).

Setelah penandatanganan perjanjian damai $M o U$ antara NKRI - GAM tahun 2006 di Helsynki-Finlandia, konflik di Aceh termasuk tanah Gayo secara berangsur-angsur mulai pulih, namun harmonisasi antara etnis Gayo dengan etnis Jawa tidak segera pulih karena luka konflik lama masih membekas pada kedua belah pihak.

Namun lambat laun karena karakter etnis Jawa yang cenderung mudah berbaur dengan etnis Gayo, menjadikan hubungan itu pulih kembali, stereotype negatif yang pada awalnya dilekatkan kepada etnis Jawa sebagai etnis yang tidak bisa dipercaya karena dianggap berperan sebagai penunjuk jalan dan mata mata musuh untuk menangkap dan mengeksekusi etnis Gayo semain memudar terbukti sampai sekarang etnis Gayo menerima etnis Jawa sebagai bagian dari masyarakat sosial di lingkungan terdekatnya bahkan suasana keharmonisan dan kerukunan hidup terjaga diantara keduanya. Berdasarkan 
uraian diatas tulisan ini akan membahas bagaimana karakter etnis Jawa dan karakter etnis Gayo dapat mempengaruhi persepsi antar etnis dan menyumbang keharmonisan komunikasi diantara keduanya.

\section{PEMBAHASAN}

Ketika meninjau komunikasi yang dikaitkan dengan budaya maka pusat perhatian mengarah kepada variasi tingkah laku dan cara manusia berkomunikasi yang terjadi antara orang-orang yang berbeda etnis atau budaya. Perbedaan etnis akan menghasilkan perbedaan dalam cara-cara berkomunikasi baik berkomunikasi secara verbal maupun non verbal. Lalu apakah yang dimaksud engan komunikasi antar budaya itu? Menurut Charley H.Dood (dalam Liliweri, 2007: 12) komunikasi antarbudaya meliputi komunikasi yang melibatkan peserta komunikasi yang mewakili pribadi, antarpribadi atau kelompok dengan tekanan pada perbedaan latar belakang kebudayaannya yang mempengaruhi perilaku komunikasi para peserta. Selanjutnya GuoMing Chen dan William J.Starosta (dalam Liliweri, 2007: 13) menyatakan bahwa komunikasi antar budaya adalah proses negosiasi atau pertukaran sistim simbolik yang membimbing perilaku manusia dan kelompok. Selanjutnya menurut Stewart L. Tubbs, komunikasi antarbudaya adalah komunikasi antara orang-orang yang berbeda budaya (baik dalam arti ras, etnik, atau perbedaanperbedaan sosio ekonomi)

Dari berbagai defenisi komunikasi antarbudaya tersebut dapat disimpulkan bahwa dalam proses komunikasi antarbudaya tidak ada kepastian bagaimana proses persepsi dan tanggapan etnis lain yang akan timbul, apalagi jika diantara kedua etnis yang berinteraksi kurang memahami budaya masing-masing. Artinya semakin besar kesenjangan budaya yang menjadi realitasnya maka akan semakin berkurang tingkat kepastian yang bisa diprediksi dari proses interaksi yang terjadi antar etnis. Kesenjangan budaya yang terjadi itu bisa didekatkan dengan adanya rasa empati yang mendukung terjadinya komunikasi yang harmonis antar etnis.

Etnis Jawa adalah golongan etnis yang memiliki jumlah terbesar di Indonesia. Sebagian besar etnis ini bertempat tinggal di Pulau Jawa. Sebagian lainnya lagi tersebar di berbagai tempat di seluruh penjuru Indonesia.Dalam perantauannya di berbagai tempat di seluruh penjuru Indonesia etnis Jawa pada umumnya selalu mampu beradaptasi dengan baik dengan masyarakat setempat dimana mereka hidup berdampingan. Salah satu faktor penyebabnya adalah kekuatan karakter yang dimiliki etnis Jawa sebagai etnis perantau yang mudah akrab dan cepat menyesuaikan diri dengan lingkungan sekitar. Menurut hasil penelitian Heriani Wijayanti dan Fivi Nuwianti (2010:119) karakter utama yang menonjol pada suku Jawa adalah senang berkumpul dan hidup bermasyarakat berdasarkan pada sikap adil, gotong royong dan saling berbagi. Selain itu dalam kehidupannya etnis Jawa juga menerapkan sikap selalu bersyukur kepada Tuhan atas apa pun yang telah diberikan kepadanya dan selalu percaya bahwa segala sesuatu yang terjadi sudah menjadi takdir baginya. Hal inipun sesungguhnya sejalan dengan semboyan orang Jawa "mangan ora mangan nek kumpul" yang mencerminkan budaya selalu ingin berkumpul dan menyatu dengan lingkungan sosialnya (Melalatoa, 1995).Selain itu menurut Herusatoto (2008) orang Jawa juga memiliki prinsip hidup selalu nrima (ikhlas). Nrima berarti tidak menginginkan apa yang menjadi milik orang lain serta tidak iri hati terhadap kebahagiaan orang lain. Inilah salah satu faktor yang mempengaruhi karakter etnis Jawa sehingga selalu bisa berdamai dengan orang lain dan bersatu di lingkungan sosialnya dimanapun mereka berada.

Etnis Gayo dapat digolongkan sebagai etnis yang memiliki pandangan luas dan terbuka terhadap etnis lainnya di Provinsi 
Aceh. Mereka dapat hidup saling berdampingan dengan etnis-etnis pendatang misalnya dengan etnis Jawa, etnis Minangkabau, etnis Tionghoa, etnis Batak/Mandailing dan beberapa etnis lainnya. Sebagian orang orang Aceh pesisir menyatakn bahwa etnis Gayo adalah orangorang yang berasal dari Batak biasa disebut Batak 12 atau Aceh Batak, karena menurut cerita orang-orang terdahulu pada saat pemerintahan Sisingamangaraja di daerah Batak, ia mengutus 12 orang Batak pergi ke arah daerah Gayo, maka utusan itulah selanjutnya berkembang di daerah sana sehingga menjadi warga Gayo (Cut Banta Rafinis, 2004)

Karakter etnis gayo pada umumnya cenderung lebih tenang dan tidak terlalu ekspresif dalam bersikap. Namun etnis Gayo selalu bersifat terbuka terhadap etnis pendatang. Etnis Gayo juga memiliki sifat suka bergotong royong, terutama ketika menyelenggarkan pesta perkawinan. Hajatan perkawinan merupakan perwujudan gotong royong masyarakat setempat, dimana banyak anak-anak muda yang diminta bantuannya dalam bergotong royong.

d. Stereotype

Kesulitan komunikasi akan muncul dari penstereotipan (stereotyping), yakni menggeneralisasikan orang-orang berdasarkan sedikit informasi dan membentuk asumsi orang-orang berdasarkan keanggotaan mereka dalam suatu kelompok. Dengan kata lain, penstereotipan adalah proses menempatkan orang-orang ke dalam kategori-kategori yang mapan, atau penilaian mengenai orang-orang atau objek-objek berdasarkan kategori-kategori yang sesuai, ketimbang berdasarkan karakteristik individual mereka. Banyak definisi stereotype yang dikemukakan oleh para ahli, kalau boleh disimpulkan, stereotip adalah kategorisasi atas suatu kelompok secara serampangan dengan mengabaikan perbedaan-perbedaan individual. Menurut Baron dan Paulus (dalam Sobur, 2009: 391) ada beberapa faktor yang menyebabkan adanya stereotip. Pertama, sebagai manusia kita cenderung membagi dunia ini ke dalam dua kategori : kita dan mereka. Orang-orang yang kita persepsi di sebagai kelompok di luar kita, dipandang lebih mirip satu sama lain karena kita kekurangan informasi mengenai mereka, kita cenderung menyamaratakan mereka semua, dan mengangap mereka sebagai homogen. Kedua, stereotip tampaknya bersumber dari kecenderungan kita untuk melakukan kerja kognitif sedikit mungkin dalam berpikir mengenai orang lain.Kita berasumsi bahwa kita tahu banyak tentang mereka itulah sebabnya kita melabelkan sifat-sifat tertentu pada orang lain di luar kelompok kita. Dengan kata lain, stereotip menyebabkan persepsi selektif tentang orangorang dan segala sesuatu disekitar kita. Stereotip dapat membuat informasi yang kita terima tidak akurat. Pada umumnya, stereotip bersifat negative, tapi adakalanya juga positif. Stereotip tidak berbahaya sejauh kita simpan di kepala kita, namun akan bahaya bila diaktifkan dalam hubungan manusia. Stereotip dapat menghambat atau mengganggu komunikasi itu sendiri. Contoh dalam konteks komunikasi lintas budaya misalnya, kita melakukan persepsi stereotip terhadap orang Padang bahwa orang Padang itu pelit. Lewat stereotip itu, kita memperlakukan semua orang Padang sebagai orang yang pelit tanpa memandang pribadi atau keunikan masing-masing individu. Orang Padang yang kita perlakukan sebagai orang yang pelit mungkin akan tersinggung dan memungkinkan munculnya konflik. Atau misal stereotip terhadap orang Batak bahwa mereka itu kasar. Dengan adanya persepsi itu, kita yang tidak suka terhadap orang yang kasar selalu berusaha menghindari 
komunikasi dengan orang batak sehingga komunikasi dengan orang batak tidak dapat berlangsung lancar dan efektif. Stereotip terhadap orang afrika-negro yang negatif menyebabkan mereka terbiasa diperlakukan sebagai kriminal. Contohnya, di Amerika bila seseorang (kulit putih) kebetulan berada satu tempat/ruang dengan orang negro mereka akan, secara refleks, melindungi tas atau barang mereka, karena menggangap orang negro tersebut adalah seorang pencuri. Namun, belakangan, stereotip terhadap orang negro sudah mulai berkurang terlebih sejak presiden Amerika saat ini juga keturunan negro. Orang Indonesia sendiri di mata dunia juga sering distereotipkan sebagai orangorang 'anarkis' , 'bodoh', konservatifprimitif, dll.(Mulyana, 2008;237-243). Walaupun jarang sekali stereotipe itu sepenuhnya akurat, namun beberapa penelitian statistik menunjukkan bahwa dalam beberapa kasus stereotipe sesuai dengan fakta terukur.

Stereotip bisa berubah seiring dengan realitas yang berubah di lapangan. Sebagai contoh ketika orang Amerika memiliki stereotip yang negatif terhadap warga kulit hitamnya, tetapi ketika presiden Barack Obama yang berkulit hitam terpilih menjadi presiden dan berhasil memimpin Amerika selangkah lebih maju lagi ,maka realitas ini menjadikan stereotip negatif mulai memudar.

Hal yang sama juga terjadi di kalangan etnis Gayo dan Jawa yang pada awalnya mereka berkonflik ketika masa DOM, namun lambat laun stereotip negatif tentang etnis Jawa terkikis seiring dengan waktu karena karakter etnis Jawa yang cenderung Nrima dan mengalah dengan penduduk sekitarnya. Disamping itu etnis Jawa juga suka bergotong royong dan bersopan santun dalam pergaulan sosialnya.

Soekanto (dalam Faisal, 1999:17) menjelaskan lebih lengkap mengenai faktor- faktor yang menjadi pendukung dan mempermudah terjadinya asimilasi. Pertama adalah toleransi, yaitu sikap dan tindakan yang saling memberikan peluang atau kesempatan kepada pihak lain untuk melakukan sesuatu sehingga benih benih pertentangan antar individu ataupun antarkelompok dapat terhindarkan.

Kedua adalah kesempatan (Opportunity) di bidang ekonomi yang sama rata. Kesempatan ataupun peluang dalam bidang ekonomi yang seimbang akan mengurangi peluang terjadinya ketimpangan antar kelompok secara ekonomi, sehingga pertentangan dan konflik dapat dicegah. Dalam aspek ekonomi etnis Jawa dan etnis Gayo pada umumnya sama-sama bermata pencaharian sebagai petani. Keahlian bertani etnis Jawa menjadi daya tarik bagi etnis Gayo untuk mempelajari cara bertani dari etnis Jawa. Dalam hal ini etnis Jawapun dengan senang hati selalu berbagi pengetahuan dengan etnis Gayo sehingga hal ini membentuk persepsi positif bagi orang Gayo terhadap etnis Jawa.

Ketiga adalah sikap penghargaan terhadap orang asing dan kebudayaannya. Asimilasi akan semakin gampang terjadi apabila adanya suatu sikap dimana masyarakat tersebut menghargai kebudayaan di luar kelompok itu sendiri.Artinya ketika etnis Gayo mampu menghargai kebudayaan etnis Jawa maka memungkinkan terjadinya asimilasi kebudayaan antara etnis Jawa dan Gayo.

Keempat adalah adanya Sikap terbuka dari golongan penguasa dalam masyarakat. Dibutuhkan dorongan dari para elit pemerintahan khususnya Presiden serta anggota DPR untuk meramu Undang undang yang memberikan terbukaan terhadap mereka yang berbeda seperti diijinkannya perayaan Hari Imlek oleh warga Tionghoa yang sebelumnya sempat dilarang. 
Kelima, adalah persamaan dalam unsur unsur kebudayaan. Hal ini tanpa anda sadari memang betul, asimilasi akan semakin mudah terjadi apabila adanya kesamaan budaya ataupun unsur unsurnya, oleh karena itu kebudayaan dari Arab mudah berasimilasi dengan masyarakat Indonesia dikarenakan kesamaan ajaran tentang Islam.

Ketujuh, adalah perkawinan campuran (amalgamation). Salah satu jalan terjadinya asimilasi adalah perkawinan antara dua insan manusia yang berbeda seperti pribumi dan nonpribumi, berbeda ras, berbeda kelompok, berbeda golongan, berbeda negara dan bahkan berbeda agama (untuk beberapa situasi dapat menghasilkan perpecahan bukan asimilasi). Betul memang, perkawinan campuran akan mampu mengurangi perbedaan diantara mereka apalagi bila sudah banyak diantara kedua kelompok tersebut yang melakukan perkawinan campuran tersebut sehingga mau tidak mau kedua ras ataupun kelompok yang berbeda lambat laun akan menjadi satu kelompok (asmilasi terjadi).

Kedelapan, adalah kehadiran musuh bersama. Persatuan dan asimilasi akan terjadi bila terjadi situasi dimana terdapat ancaman dari luar berupa musuh bersama. Contoh, Malaysia dan Indonesia biasanya sering berkonflik, akan tetapi apabila USA menyerang negara Muslim seperti Pakistan ataupun Afganistan, maka Malaysia dan Indonesia akan bersatu untuk membebaskan sesama negara muslim dari musuh bersama mereka. Umumnya asimilasi musuh bersama diikat oleh ajaran agama.

Komunikasi antar budaya pada dasarnya adalah proses komunikasi yang melibatkan orang-orang berbeda budaya. Batas untuk membedakannya adalah latar belakang budaya yang berbeda dari orang-orang yang melakukan proses komunikasi tersebut. Aspek-aspek budaya dalam komunikasi seperti bahasa, isyarat non verbal, sikap, kepercayaan, watak, nilai dan orientasi pikiran akan lebih banyak ditemukan sebagai perbedaan besar yang sering kali menyebabkan distorsi dalam komunikasi antar budaya. Namun, meskipun banyak perbedaan tetap ada kepentingankepentingan bersama untuk melakukan ineraksi dan komunikasi (Alex. 2001: 117). Harus diakui bahwa budaya menentukan caracara kita yang unik dalam berkomunikasi, topik-topik pembicaraan seperti siapa yang boleh berbicara, siapa yang tidak boleh diajak bicara, bagaimana cara berbicara dan kapan boleh berbicara, bahasa tubuh yang boleh dan tidak boleh digunakan, konsep ruang, makna waktu, dan sebagainya, sangat bergantung kepada aturan budaya masing masing etnis (Mulyana, 2011: 3).

Kebudayaan tentunya akan mempengaruhi individu. Selain pengaruh pengalaman pribadi, kehadiran nilai-nilai, adat istiadat, kebiasaan atau kepercayaan yang terdapat dalam setiap kebudayaan, dapat mempengaruhi perbedaan pengalaman seseorang. Unsur-unsur kebudayaan ideal berfungsi mengatur, mengendalikan, dan mengarahkan masyarakatnya dalam bertingkah laku, termasuk tingkah laku komunikasi.

Terkait dengan cara bertingkah laku dalam berkomunikasi akan terlihat ketika seseorang melakukan proses persepsi. Secara sederhana, persepsi dapat diartikan sebagai penafsiran atau pemberian makna terhadap suatu stimuli. Ketika etnis Jawa berinteraksi dengan etnis Gayo maka hal tersebutpun tak luput dari pengaruh persepsi yang tumbuh diantara keduanya.Disinilah nilai-nilai budaya mempengaruhi persepsi atau penafsiran suatu obyek. Oleh karena nilai-nilai budaya itu berbeda-beda dari suatu kebudayaan ke kebudayaan lainnya maka persepsi mengenai suatu obyek belum tentu sama antara suatu masyarakat dengan masyarakat lainnya.

$$
\text { Hakikat interaksi antar budaya }
$$
adalah mengenai adanya penerimaan dan penghargaan terhadap suatu kebudayaan, baik 
kebudayaan sendiri maupun kebudayaan orang lain. Setiap orang ditekankan untuk saling menghargai dan menghormati setiap kebudayaan yang ada di masyarakat. Apapun bentuk suatu kebudayaan harus dapat diterima oleh setiap orang tanpa membedabedakan antara satu kebudayaan dengan kebudayaan yang lain.

Lebih lanjut, hal utama yang sangat penting dalam hubungan antar budaya adalah komunikasi. Dalam berkomunikasi dengan konteks keberagaman kebudayaan kerap kali menemui masalah atau hambatanhambatan yang tidak diharapkan sebelumnya. Misalnya saja dalam penggunaan bahasa, lambang-lambang, nilai atau norma-norma masyarakat dan lain sebagainya. Pada hal syarat untuk terjalinya hubungan itu tentu saja harus ada saling pengertian dan pertukaran informasi atau makna antara satu dengan lainnya. Dari itu mempelajari komunikasi dalam sebuah hubungan antar budaya merupakan satu hal yang tidak dapat dipisahkan.

Komunikasi dan budaya mempunyai hubungan timbal balik, seperti dua sisi mata uang. Budaya menjadi bagian dari prilaku komunikasi dan pada gilirannya komunikasi pun turut menentukan memelihara, mengembangkan atau mewariskan budaya. Oleh karenanya dapat dikatakan bahwa komunikasi adalah Budaya dan Budaya adalah komunikasi. Pada satu sisi, komunikasi merupakan suatu mekanisme untuk mensosialisasikan norma-norma budaya masyarakat, baik secara horizontal dari suatu masyarakat kepada masyarakat lainnya, ataupun secara vertikal dari suatu generasi kegenerasi berikutnya. Pada sisi lain, budaya merupakan norma-norma atau nilainilai yang dianggap sesuai untuk kelompok tertentu. Tidak banyak orang menyadari bahwa bentuk-bentuk interaksi antarbudaya sesungguhnya secara langsung atau tidak melibatkan sebuah komunikasi.

Dalam kenyataan sosial, manusia tidak dapat dikatakan berinteraksi sosial kalau dia tidak berkomunikasi. Dapat dikatakan pula bahwa interaksi antar-budaya yang efektif sangat tergantung dari komunikasi antarbudaya. Maka dari itu kita perlu tahu apaapa yang menjadi unsur-unsur dalam terbentuknya proses komunikasi antarbudaya, yang antara lain adalah adanya komunikator yang berperan sebagai pemrakarsa komunikasi; komunikan sebagai pihak yang menerima pesan; pesan/simbol sebagai ungkapan pikiran, ide atau gagasan, perasaan yang dikirim komunikator kepada komunikan dalam bentuk simbol. Komunikasi itu muncul, karena adanya kontak, interaksi dan hubungan antar warga masyarakat yang berbeda kebudayaannya.

Secara alamiah, proses komunikasi antar budaya berakar dari relasi antarbudaya yang menghendaki adanya interaksi sosial. Karena itu, dalam kenyataan sosial disebutkan bahwa manusia tidak dapat dikatakan berinteraksi sosial kalau dia tidak berkomunikasi. Demikian pula, dapat dikatakan bahwa interaksi antarbudaya yang efektif sangat tergantung dari komunikasi antarbudaya. Konsep ini sekaligus menerangkan bahwa tujuan komunikasi antarbudaya akan tercapai (komunikasi yang sukses) bila bentuk-bentuk hubungan antarbudaya menggambarkan upaya yang sadar dari peserta komunikasi untuk memperbarui relasi antara komunikator dengan komunikan, menciptakan dan memperbaharui sebuah manejemen komunikasi yang efektif, lahirnya semangat kesetiakawanan, persahabatan, hingga kepada berhasilnya pembagian teknologi, mengurangi konflik yang seluruhnya merupakan bentuk dari komunikasi antarbudaya.

Sesungguhnya kebutuhan emosional dan intelektual itu kita peroleh pertama-tama dari keluarga kita, lalu dari orang-orang dekat disekeliling kita seperti kerabat dan kawankawan sebaya dan barulah dari masyarakat umumnya. Orang yang tidak memperoleh kasih sayang dan kehangatan dari orang-orang disekelilingnya cendrung agresif. Pada 
gilirannya, agresifitas ini melahirkan kekerasaan terhadap orang lain. Stewart menunjukkan bahwa orang yang terkucil secara sosial cendrung lebih cepat mati. Selain itu, kemampuan berkomunikasi yang buruk ternyata mempunyai andil dalam kematian seseorang (Suranto Aw. 2010: 23).

Dari berbagai uraian di atas maka dapat dikatakan manusia adalah merupakan makhluk individu sekaligus sebagai makhluk sosial. Sebagai makhluk sosial, dalam upaya pencapaian kebutuhannya, manusia harus berhadapan dengan manusia lain yang juga mempunyai kepentingan untuk memenuhi kebutuhan individualnya, sehingga kerap terjadi suatu konflik kepentingan antarmanusia. Sebagai jalan tengah untuk mengurangi resiko terjadinya konflik, dimunculkan suatu nilai, norma, atau aturan bersama yang disebut dengan etika bersama.

\section{SIMPULAN}

Keharmonisan komunikasi yang terjadi antar etnis Gayo dan Jawa juga disebabkan adanya sikap toleransi yang besar dari etnis Jawa yang memiliki karakter Nrima sehingga cenderung mengalah untuk menghindari konflik dengan etnis setempat. Di samping itu kedua etnis ini juga memiliki kesamaan dalam memilih agama Islam sebagai pegangan kehidupan. Bermodalkan rasa saling menghargai dan menghormati antar kedua etnis ini, maka keunikan budaya etnis lain tidak menjadi masalah justru menjadi daya tarik tersendiri bagi masyarakat Gayo. Sehubungan simpulan diatas maka saran penelitian ini adalah agar kedua etnis tetap menjaga dan saling menghormati adat budaya masing-masing serta saling menerima kelebihan dan kekurangan etnis masingmasing. Etnis Jawa perlu kiranya mempertahankan sikap terbuka, bersahabat dan saling bertoleransi dengan etnis Gayo. Disamping itu juga perlu kiranya menghilangkan persepsi negatif kepada etnis lain, sedemikian hingga keharmonisan komunikasi antar etnis tetap akan terpelihara.

\section{DAFTAR PUSTAKA}

Alex, H.R dkk. (2001). Komunikasi Antarbudaya. Pusat Penerbit Universitas Terbuka, Jakarta.

Herusatoto, B, (2001), Simbolisme dalam Budaya Jawa, Hanindita Graha Widia, Yogyakarta

Liliweri, A, (2007), Makna Budaya dalam Komunikasi Antar Budaya, LkiS Pelangi Aksara, Yogyakarta

Mulyana, D. \& Rakhmat, J. (2005). Komunikasi Antarbudaya: Panduan Berkomunikasi dengan Orang-orang Berbeda Budaya. Bandung: Remaja Rosdakarya. . (2011). Komunikasi Lintas Budaya. Bandung: Remaja Rosdakarya.

Nuraeni, H.G, dan Muhammad A., (2012). Studi Budaya Indonesia. Bandung: Pustaka Setia.

Rafinis, C.B., (2004). Adat Istiadat Budaya Gayo Takengon Nenggeriantara Nanggro Aceh Darussalam. Tahun Budaya NAD.

Suranto Aw. (2010). Komunikasi Sosial Budaya. Graha Ilmu. Yogyakarta.

Wijayanti, H., dan Fivi N, (2010), Kekuatan Karakter dan Kebahagiaan pada Suku Jawa, Jurnal Psikologi Volume 3 no 2 Juni 2010, Fakultas Psikologi, Universitas Indonesia, Depok 